\title{
Discussion on the Cost Accounting Work under New Financial System for Colleges and Universities
}

\author{
Linhong GONG \\ Department of finance and accounting \\ Wuhan University of Technology \\ Wuhan, China \\ e-mail: glinhong@126.com
}

\begin{abstract}
Cost accounting helps colleges and universities to improve their management and efficiency and it is also the priority of educational reform among those high institutions. "Financial System for colleges and universities" issued by Ministry of Finance in $\mathbf{2 0 1 3}$ plays a leading role in guiding the cost accounting for colleges and universities. In this paper, cost management is detailed explained under new Financial System for colleges and universities. It proposes that the prerequisite for cost accounting is to introduce accrual system. The concept of Costs, fees and expenses should be clarified and the content of expense accounting also needs to be specified. It proposes specific measures to convert expenditures to expenses and it also proposes to establish mechanism to check expense and expenditure and to establish cost reporting system on the basis of classification, collection and allocation of costs, fees and expenses. In summary, the paper brings forward practical ways and methods for cost accounting in colleges and universities.
\end{abstract}

Keywords-cost accounting; accounting mechanism; financial system for colleges and universities

\section{THE SIGNIFICANCE AND OVERALL REVIEW OF THE AMENDMENT}

The newly revised "Financial System for colleges and universities" by Ministry of Finance and Ministry of Education was formally put into effect from January 1, 2013. One of the highlights for the newly revised "Financial System for colleges and universities" is that a special "cost management chapter" in Chapter 10 was set up to require colleges and universities of cost accounting. The thought of using cost accounting means to establish educational information system has come into being in Western countries in the early 1960s. In China universities are non-profit organizations which do not calculate profit and loss, nor the accounting costs, thus limits the development of university education cost accounting theory and practice [1]. With the innovative development of education in the new situation, to carry out cost management in university has become imperative. Colleges and universities have a diversified source of funding. On the one hand, colleges and universities have to meet the government's budget management requirements; on the other hand colleges and universities also have to provide services for other interested universities to acquire information. Cost accounting is an important basis for reasonable education cost share. Higher Education in China is mainly invested by organizers, education receivers reasonably share cultivation cost, and the universities and colleges set up foundations to accept public donations and other funding mechanisms. Internal cost management in universities and colleges is an important way to evaluate the fund performance. The colleges and universities' asset management, which truly and completely reflect the asset using situation, reasonably allocate and efficiently use of assets and prevent loss of assets, has an important role and significance to improve capital efficiency [2]. Higher Education Development has entered from expansion to a new stage of enhancing the quality of education, and to strengthen cost management is the requirement of scientification and refinement of university financial management.

There are total seven articles in Chapter 10 of "cost management" which mainly includes: (1) Colleges and universities should implement internal cost management based on development needs; (2) Definition of the cost (asset cost or loss for completion of teaching, research, management and other activities); (3) The allocation method of cost transfer; (4) The definition of cost accounting; (5) Cost items collected in accordance with its purpose (education costs, research expenses, management fees, retirement and other expenses) and their respective definition and content; (6) The cost collection methods; (7) Requirements to refine cost accounting, establishment of cost and related expenses check mechanism, cost analysis reporting system, etc. [3].

\section{THE INTRODUCTION OF ACCRUAL SYSTEM IS THE PREMISE OF COST ACCOUNTING}

Before the introduction of the new financial system, there are mainly two cost accounting methods for colleges and universities' education cost: Survey method and accounting adjustment method.

The survey method is to acquire the education cost data through appropriate adjustments of education funding statistics or the results of a sample survey. The main advantages of this method are: (1) to obtain educational cost data at a very low cost in a very short period of time; (2) establishing mathematical modeling through past survey, and to calculate the educational cost in specific period and a specific project through educational cost function.(3) through 
economic statistics to estimate the opportunity cost of education. The biggest drawback of the survey method is that the data of educational cost is neither accurate nor systematical. The survey method mainly takes educational fund as statistical indicators, but educational fund contains some content which does not belong to educational cost, and lacks some items that shall be included in educational cost.

Accounting adjustment method. It is a way to convert, in accordance with a set of rules, the educational expenditure data into educational cost data, which is based on the accounting record of educational expenditure. The current accounting system in China higher educational institutes specifies that cash basis should be adopted in their accounting. As accrual system is the basis for scientific cost accounting, cash basis directly impacts the accuracy of cost accounting. The mentioned act focuses on the establishment of uniform adjustment rules, with cash as the accounting basis and makes adjustment in accounting by applying accrual system. The accounting adjustment method lacks accuracy for two reasons. Firstly, higher educational institutes have no uniform adjustment rules. Secondly, the educational cost based on current accounting data belongs to imputed cost. As a result, the accounting adjustment method didn't get popularity among universities and colleges in their accounting.

Educational cost accounting must abide by the principle of accrual system. New financial system introduces accrual system while retaining the cash basis system to reflect the actual expenditure of educational budget, which lays a foundation for cost accounting as well as further adjust the ratio between revenue and cost [4]. Accrual system has a number of advantages. Firstly, accounting can be done immediately when transactions and substantial matters are realized. Secondly, the depreciation of fixed asset can accurately reflect the total amount, stock and utilization of fixed asset. What's more, the expenditure in fixed asset can be calculated as a part of period charges by means of depreciation so as to obtain the current-period costs of schooling, scientific research and management activities.

\section{The Cost Accounting Must MeEt the REQUIREMENT OF COST AND EXPENSES MANAGEMENT IN “THE FINANCE REGULATIONS OF COLLEGES"}

\section{A. Defining the Scope of Cost and Expense Management}

In "The Finance Regulations of Colleges", article 56 stipulates that "colleges and universities should implement the internal cost management in its own interest". Firstly, the article makes it clear that cost and expense management is a significant means of promoting its own development. Colleges focus on different aspects of cost and expense management due to their different degree of development. Thus, colleges should create according conditions for their cost and expense management. Secondly, while colleges endeavor to meet the need of their cost and expense management, they must facilitate the performance evaluation of the use of funds in institutions of higher learning conducted by related authorizations and the department of finance. Universities should strengthen cost and expense management to make it integrated, coordinated and systematized.

\section{B. Make a Distinction between Cost Expense and Payment and Propose Concrete Methods of Transferring Payment to Expense}

The article 57 in "The Finance Regulations of Colleges" prescribes that expense is the asset losses of current period for teaching, research and management activities. The article 58 stipulates that colleges, based on payment management, should include profits and related payments in the accounting year into expense of current period. The regulations also says that profits and related payments in two or more accounting years should be calculated as a part of expense in accordance with relevant regulations and in the form of depreciation of fixed asset and amortization of intangible assets

The above articles make it clear that the cost is the objectification of expense while expense is the payment of current year. Payment may be a part of cost and expense in the current period. However, the expense of current period is not necessarily counted as a part of cost and expense of current period (the differences and relations among cost, expense and payment are shown in table 1).

Payment on fixed asset should be depreciated in accordance with appropriate regulations [5]. In addition, capital expenditure in college must be amortized over certain accounting years. For instance, a college spent 800 million on employment in 2013, which can be considered as payment and educational expense as well. Take another case for example. It purchased teaching equipment worth 4 million RMB with an estimated 10-year service period. Then depreciated 400 thousand should be recorded into the educational expense of 2013 instead of the total payment of 400 million. Making distinction among cost, expense and payment is of great significance for the cost and expense management, for better accounting and gathering internal cost and expense and for establishing a mechanism for reconciliation of cost, expense and payment.

Article 58 emphasizes that college should, based on expense and cost management, further classify and distinguish payment within the framework of cash basis system and then payment should be converted into cost and expense in accrual system and be recorded into currentperiod cost, which plays the role of cohesion and coordinating [6].

TABLE I. THE RELATIONS OF UNIVERSITY COST AND EXPENDITURE

\begin{tabular}{|c|c|c|}
\hline Types & Differences & relations \\
\hline $\begin{array}{l}\text { College } \\
\text { cost }\end{array}$ & $\begin{array}{l}\text { The objectification of } \\
\text { college expense }\end{array}$ & \multirow{3}{*}{$\begin{array}{l}\text { They are all loss for conducting } \\
\text { teaching, research and management } \\
\text { activities. } \\
\text { In certain conditions, payment is } \\
\text { expense or can be transformed as } \\
\text { expense. In other words, revenue } \\
\text { expenditure is a kind of expense and } \\
\text { capital expenditure can be } \\
\text { transformed as expense. } \\
\text { In terms of size, college payment is } \\
\text { larger than expense which is larger } \\
\text { than cost. }\end{array}$} \\
\hline $\begin{array}{l}\text { College } \\
\text { expense }\end{array}$ & $\begin{array}{l}\text { The asset loss; current- } \\
\text { period payment }\end{array}$ & \\
\hline $\begin{array}{l}\text { Cost } \\
\text { payment }\end{array}$ & $\begin{array}{l}\text { All the capital loss; } \\
\text { not necessarily be the } \\
\text { expense and cost of } \\
\text { current period }\end{array}$ & \\
\hline
\end{tabular}




\section{Specify the Content, Classification, Collection and Distribution of Cost Accounting}

According to Article 59 of the Financial Rules, the term "cost accounting" refers to collection, distribution and calculation of all kinds of fees incurred during the business activities of an institution of higher education according to relevant accounting objects and accounting methods. In fact, the process of cost accounting is to collect expenses and distribute them according to relevant cost objects. Article 60 of the Financial Rules states that according to classification of uses, expenses shall mainly include expenses for education, expenses for scientific research, expenses for management and expenses for retirement and other expenses. Connotations and contents of expenses of all kinds refer to table 2 .

TABLE II. CONNOTATIONS AND CONTENTS OF VARIOUS EXPENSES IN COLLEGES AND UNIVERSITIES

\begin{tabular}{|c|c|c|}
\hline $\begin{array}{l}\text { Type of } \\
\text { expense }\end{array}$ & Connotation & Content \\
\hline $\begin{array}{l}\text { Expenses for } \\
\text { education }\end{array}$ & $\begin{array}{l}\text { All fees incurred dur- } \\
\text { ing teaching, tutoring, } \\
\text { student affairs and } \\
\text { other educational } \\
\text { activities conducted by } \\
\text { an institution of higher } \\
\text { education. }\end{array}$ & $\begin{array}{l}\text { It's equal to the following fees } \\
\text { of original Financial Rules, } \\
\text { including teaching expenses in } \\
\text { the part of business expense, } \\
\text { main part of expenses for } \\
\text { student affairs, expenses of } \\
\text { welfare and insurance for } \\
\text { faculty, expenses incurred on } \\
\text { teaching activities or should be } \\
\text { shared of activity assistant } \\
\text { department and logistic } \\
\text { expenses except the part which } \\
\text { should be shared. }\end{array}$ \\
\hline $\begin{array}{l}\text { Expenses for } \\
\text { scientific } \\
\text { research }\end{array}$ & $\begin{array}{l}\text { All fees incurred on an } \\
\text { institution of higher } \\
\text { education for the } \\
\text { purpose of completing } \\
\text { the scientific research } \\
\text { tasks it undertakes. }\end{array}$ & $\begin{array}{l}\text { It's equal to the following } \\
\text { expenses of original Financial } \\
\text { Rules, including main part of } \\
\text { expenses for scientific research } \\
\text { activities, expenses of welfare } \\
\text { and insurance for researchers, } \\
\text { expenses incurred on teaching } \\
\text { activities of activity assistant } \\
\text { department and logistic } \\
\text { expenses except the part which } \\
\text { should be shared. }\end{array}$ \\
\hline $\begin{array}{l}\text { Expenses for } \\
\text { management }\end{array}$ & $\begin{array}{l}\text { All fees incurred for } \\
\text { the purpose of com- } \\
\text { pleting a college's } \\
\text { administrative tasks }\end{array}$ & $\begin{array}{l}\text { It's equal to the following } \\
\text { expenses of original Financial } \\
\text { Rules, including main part of } \\
\text { administration expenses, } \\
\text { expenses of welfare and } \\
\text { insurance for officials and } \\
\text { logistic expenses except the part } \\
\text { which should be shared. }\end{array}$ \\
\hline $\begin{array}{l}\text { Expenses for } \\
\text { retirement }\end{array}$ & $\begin{array}{l}\text { The general expenses } \\
\text { borne by an institution } \\
\text { of higher education for } \\
\text { retirees in terms of } \\
\text { social security and } \\
\text { welfare benefits. }\end{array}$ & $\begin{array}{l}\text { Relative parts of expenses for } \\
\text { welfare in the original Financial } \\
\text { Rules }\end{array}$ \\
\hline $\begin{array}{l}\text { Other } \\
\text { expenses }\end{array}$ & $\begin{array}{l}\text { All fees that cannot be } \\
\text { attributed by an institu- } \\
\text { tion of higher educa- } \\
\text { tion to the aforesaid } \\
\text { fees as mentioned in } \\
\text { this Article }\end{array}$ & $\begin{array}{l}\text { including subsidies to affiliated } \\
\text { entities, expenditure turned over } \\
\text { to the superior entity, financial } \\
\text { expenses, donation expenditure } \\
\text { and so forth }\end{array}$ \\
\hline
\end{tabular}

\section{Specify Methods of Cost Accounting}

According to article 62 of the Financial Rules, an institution of higher education shall, in light of actual demands, gradually specify cost accounting, and conduct accounting of total educational costs and cost per student of college, faculties and majors. The accounting of costs of scientific research activities shall be specified to scientific research projects. The Financial Rules requires that institution of higher education should take different measures to conduct cost accounting of educational costs and costs for scientific research according to their actual demands. The path of educational costs: Total educational costs of the institution of higher learning (cost per student)--Total educational costs of colleges (cost per student)--Total educational costs of faculties (cost per student)--Total educational costs of majors (cost per student). The accounting path of costs for scientific research expenses: Total costs for scientific research of the institution of higher learning--costs of each scientific program.

The accounting path demonstrates that cost accounting should be conducted from high-level cost to low-level cost, from total costs to average costs, from easy-to-conduct costs to difficult-to-conduct costs. Smaller unit of cost accounting would have more indirect fees which need to be shared, which in turn would make conduction of cost accounting more complicated. The detailed rules for implementation of the cost accounting of institutions of higher education shall be formulated by the public finance department of the State Council in conjunction with the competent education department so as to ensure the authority and standardization of specification and increase the comparability of cost accounting information.

\section{ESTABLISH THE MECHANISM FOR VERIFICATION AND THE SYSTEM FOR ANALYSIS AND REPORT OF COSTS AND EXPENSES AND OTHER RELEVANT EXPENDITURES}

According to the third clause of Article 62 of the Financial Rules, an institution of higher education implementing internal management of costs and expenses shall establish the mechanism for verification of costs and expenses and other relevant expenditures, and the system for analysis and report on costs and expenses. It manifests that institutions of higher education should meet two requirements in the aspect of cost management as follows: First, management requirements of costs should be considered when conducting cost accounting. A verification mechanism should be established to realize conversion and verification between expenditures and costs and expenses. For example: In 2013, an institution of higher education had total expenses of 0.1 billion RMB, among which expenses for education takes up 80 million RMB and the left 20 million RMB was spent on expenses for scientific research, management, operation and expenditure turned over to the superior entity. The expenses for education of 80 million RMB include 50-million-RMB purchasing expenses for fixed assets. The purchasing expenses for fixed assets depreciate 0.5 million RMB per year. The calculation formula of verification of costs and expenses and relevant 
expenditures is: Expenses for education $=$ costs and expenses + (purchasing expenses for fixed assets + depreciation fees of fixed assets).

That is: 80 million $\mathrm{RMB}=(3000+50)+(5000-50)$

Analysis of costs and expenses should be conducted on the basis of cost accounting results. When conducting analysis of costs and expenses, it's important to compare object costs and expense standards, analyze changes of costs and expenses and reasons behind it so as to follow changing rules, operate effective cost control measure, reduce costs and expenses and increase capital using efficiency. Meanwhile, it's imperative to set relative rules and requirements for reports.

\section{CONCLUSION}

In summary, accounting and management of colleges and universities rising costs for the system level, not only is the embodiment of universities in the past 20 years financial and accounting reform achievements, but also will solve the major problems of society and will play a positive role in improving the level of university management. At the same time, a careful analysis of the shortcomings of the existing system, and continue to be improved, especially to strengthen and improve the cooperative the effect of financial system and accounting system, will pave the way for the smooth implementation of the new system.

\section{ACKNOWLEDGMENT}

This work was financially supported by Humanity and Social Science Youth foundation of Ministry of Education of China 16YJCZH014.

\section{REFERENCES}

[1] X. B. Yan, "Primary studies on cost management of tertiary education," Accountant, vol. 10, pp. 74-75, February 2013.

[2] W. F. Luo, "Research on internal cost management of tertiary education," Friends of Accounting, vol. 36, pp. 111-113, December 2013.

[3] X. Z. Li, "Non-uniformity and coordination between costing accounting and management system of institutions of higher education," Friends of Accounting, vol. 27, pp. 100-103, September 2013.

[4] D. L. Zha, X. X. Ma and M. Zhu, "Research on cost accounting measures of expenses for education for chinese tertiary education," Finance and Accounting Monthly (Theory), vol. 08, pp. 54-55, March 2008.

[5] Y. Gong, "It's imperative to standardize cost accounting rules for institutions of higher education," China Accounting News," vol. 8, pp. 3002, August 2013.

[6] S. L. Yang, "Demarcation of expenditure and expenditure in university cost accounting," Finance and Accounting Monthly, vol. 22, pp. 113-115, November 2014. 